\title{
Use of system approach in creation of educational electronic cartographic aids in Ukraine
}

\begin{abstract}
Through the example of State Scientific and Production Enterprise «Kartographia» the practical steps on publishing of educational electronic cartographic production in Ukraine are analysed. The main functions of using such products in the process of teaching as a key element of innovation techniques implementation into school education are defined. The authors represent the features of application of system approach to creation of electronic cartographic aids. The requirements to the educational electronic cartographic aids are related to the specific aspects of production tasks and technological solutions.

The most essential part of the process of creation of electronic aid is a methodic processing. The quality and efficiency of the aid are defined by it. Electronic aid general structure which includes a list of programme units, intermodular connections, terms and definitions for hyperlinks is a result of this processing.

Specificity of production tasks causes additional demands to creation of electronic aids. In the article authors consider the requirements and methodic approaches to the content, font style and color composition of electronic aids. Authors also present the recommendations for editor's work.

Due to the use of system approach to the creation of electronic cartographic aids new models of planning or giving lessons can be used and modern instructional techniques can be implemented as a practical matter.
\end{abstract}

Keywords: school cartography, electronic cartographic aids, Ukrainian cartography

\section{Introduction}

Today the modern Ukrainian society is on the eve of change of educational paradigms. Teachers are faced with a need of assimilation of innovation educational technologies, such as teleconferences, electronic mail, video books, electronic aids, learning games on different optical media, video lessons using satellite TV, multimedia systems and others. Revision of organization of teaching and learning activities is necessary and it has already begun. This revision must be aimed at increase of self-directed learning, individual and collective work of pupils, practical works and laboratory classes of research nature, extension of extra-curricular activities.

Preparing of pupils to activity in information society today and in the future demands from a teacher to use different innovation technologies in education organization. Under innovation is to be understand not only the use of innovation information technologies, computer-assisted educational programs, electronic textbooks. Innovation technologies are based on the use of the methodological system where active learning and teaching methods providing development and formation of personally, professionally and socially relevant skills of pupils through interactivization of members of educational process by means of specially created conditions of educational environment play a leading part. Interactive educational technologies are used not only for better perception and assimilation of information but for their use what allows to form the entire knowledge system in the discipline/subject and include it to own acquisition of a pupil.

\section{Analysis of researches and literature}

The analysis of literature sources has shown that the most of the first electronic cartographic aids (ECAs) were made as electronic 
reproductions/duplicates of paper aids and in the most cases did not take into account computer capabilities to present the material and this concerned not only to the visualization of the material. Rather often in the literature sources they were called CD-atlases (L.V. Novytska 2007).

However in recent times attention is specially paid to development of electronic educational cartographic publications and it may be considered as an attempt to take a serious step forward in handling a problem of creation of e-aids of new generation. In literature sources (I.L. Drohushevska 2005; L.V. Novytska 2007; V.I. Ostroukh 2011, 2013; M.I. Sherman 2003) it is discussed that in order for the electronic aid to be met proposed requirements in the best possible way it has to connect in itself functions of a textbook and a teacher, referenceand-information manual and advisor, exercise book and knowledge control system.

Along with above mentioned problems there is a problem of editorial preparation because the procedure of editorial preparation of electronic cartographic publications apart from conventional works on preparation of maps to be published has its particular features. It is just the main task of the paper to discuss these topical problems.

\section{Setting goals of the paper, statement of a problem}

To solve this problem it is recommended to use a system approach to creation of ECAs. The system approach considers an object/feature as a system consisting of many interdependent constituents which will form defined integrality having system qualities. The system approach allows the ECA to be meant not for a certain user group but to be created in such a way that it may be used by everybody. Depending on needs and already available knowledge a teacher chooses learning material, its content and schooling technology.

The creation of different knowledge presentation patterns, that in one case present features common for logic thinking, and in other case present maps with which visual thinking deals, enables improving learning process on such subjects as geography and history. Knowledge check after study of each chapter can be performed by different means (by means of tests, control questions, logical exercises etc.). Depending on how pupils have absorbed and assimilated the material if needed the learned chapter may be repeated or leaning techniques may be corrected and changed. By poor results it is possible to get to know the point of view of a teacher or a pupil about the reasons of poor assimilation of the material.

The lack of joint approach to development of lesson plans and practical courses based on existing electronic training resources on geography may be considered as a main problem concerning the methods of teaching geography. Not solving of the problem hampering noticeable the process of implementation of distance learning technologies into education practice can be explained both by its newness and its complicacy. This is because the heart of the problem lays in intersecting point of two subject fields. The first subject field is innovative information technologies, the second one methods of teaching and learning geography.

\section{Discussion}

The use of system approach by creating of electronic aid allows to extend the sphere of use of ECAs and the circle of potential users. The use of multimedia, audio and video components improves demonstrativeness of material presentation, as well enables the pupils having different pathologies (hearing disorders, vision disorders etc.) to use it. Due to it steep increase in the number of users and efficiency of use of ECA may be possible. Inclusion of listed components into electronic textbook allows to change from the cognitive model of education to the pragmatic one, in which who is teached becomes an active object of education.

The main factor by choice of informational technologies as teaching techniques should be their educational potential. However in Ukraine today an economical and technological situation is so that the choice of training resources depends not so much from their educational potential as from their cost and distribution.

It is common knowledge that one of the essential components of successful study is a use of good aids in the work of the teacher. Leading specialists in distant learning technologies, teachers, supervisors note that the aid or atlas scanned or put in electronic format should not 
be considered as electronic aid, because the basic principles of development of conventional/ paper and ECAs differ significantly.

One may say that electronic aid is a simplified version of electronic textbook which in its turn may be defined, for example, as softwareand-methodological complex which is based on the use of multimedia technologies what provides a possibility to self-study of material. The electronic aid should be evaluated by expert council and get so called "label of the Ministry of Education and Science".

Drawing on own experience and taking into account recommendations of literature sources it is worth to accentuate main demands for ECAs on geography:

- supporting of hierarchy (sequencing of presentation, dividing into sections, themes, subthemes, chapters, paragraphs etc;

- simultaneous purposeful influence on the organs of hearing and visual organs (this principle is used in electronic aids in full, as restrictions may be only computer's technical capability and electronic media capacity);

- use of cross references, as the most essential way of the material presentation, what allows to improve information content of the aid and assimilate knowledge quickly and fast (references are also widely used in conventional aids, but they, as a rule, are not overdone there, because the perception may be disturbed as a result of often turning over the pages of the aid);

- the possibility to make changes quickly (modification) and to add the content;

- supporting of an active feed-back, namely hair-trigger reaction of electronic aid to every activity of an user. Just this function promotes the self-study to the full extent, while in conventional aids it is possible to support only a passive feed-back (for example, exercises with keys).

Methodic processing is a most essential part of the process of creation of electronic aid, and the quality and efficiency of the aid are defined by it. Electronic aid general structure which includes a list of programme units, intermodular connections, terms and definitions for hyperlinks is a result of this processing. (V.I. Ostroukh 2011). During methodic processing certain problems may occur. Experience of SSPE "Kartographia" allows to avoid problems by using the following recommendations:
- to learn and use standard structuring schemes of electronic aids better;

- to involve scientists, educators of school subjects, programmers, designers for an advice;

- selection and processing of material entered (maps, photo images, pictures, texts, tables etc.). This part of work includes the main complicacy of the methodic processing - a large amount of routine time consuming work of an editor;

- by methodic processing each stage must always be accorded with programmers and designers in order not to put the very complicated problems for them that may lead to time consumption and cost increase of aid.

Specificity of production tasks causes additional demands to creation of ECAs, what rather complicates the process of their development and use. It's no coincidence that the percent of ECAs, which are meant mainly for individual work of a pupil or for use by a teacher at a lesson together with other training resources, is very low in total number of electronic aids.

At a stage of development of programme units and the system of cross references there are no difficulties as a rule, apart from pure technical ones. It should be borne in mind that the work specification worked out well is a constituent of successful work of a team of programmers and a team on the whole. The editor has always to carry out analysis of intermediary results of the work in order to reveal technical and technological errors which are mainly visual defects. Not all cartographic products may by cocreated in electronic format. They were created as a paper products, and electronic presentation requires additional compilation works (fig. 1).

The contents of electronic aids are based on the contents of school atlases and maps which were edited as conventional paper textbooks. Some experts argue that conventional editing of cartographic works is not suitable for electronic aids at all. But it is an erroneous belief, because electronic cartographic products are based on the conventional principles of editing, alongside it is necessary to carry out additional editing works (sometimes stages of work) taking into account functional possibilities of the product which is created. For editor: what must be paid attention to?

First, in electronic school book all images are scaled and in the main by enlarging one 


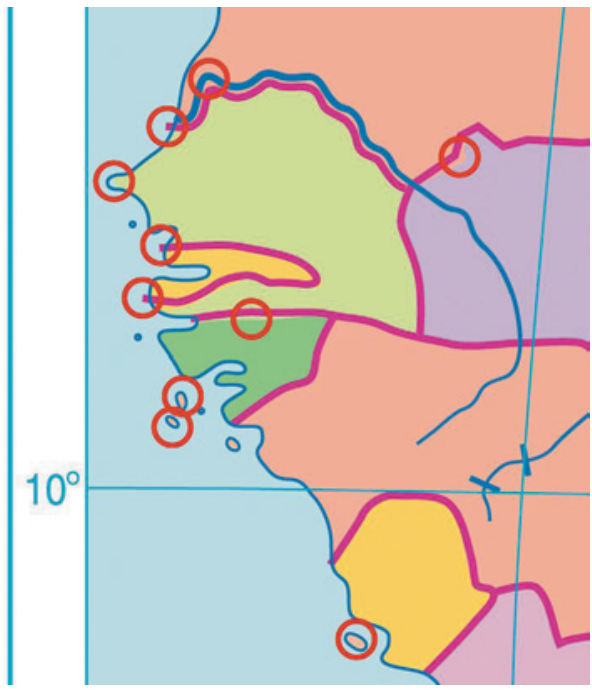

Fig. 1. Gaps of geographical framework, which became apparent by image enlargement (I.L. Drohushevska 2005; L.V. Novytska 2007; V.I. Ostroukh 2011, 2013; M.I. Sherman 2003)

can see gaps of geographical framework and subject scope (hanging lines or lines with breaks, thickness of lines, angularity of contours, shape of signs, tangency between entries etc). Special attention should be paid to raster images that by enlarging loose quality. It means that basic cartographic images or illustrative material need to be reworked.

Secondly, color composition, proper for paper maps, in electronic presentation sometimes is not read at all, especially it becomes apparent in methods of presentation of objects/features or phenomena which in legend are presented by range of colors. Rather often it is caused by video screen methods of information visualization (interactive whiteboards, projectors with screens, even tablet computers and monitors etc). Not always strength of color set can solve this problem. As a solution of this problem may be the use of animated images that facilitate the visual connection between the legend and thematic information of the map.

Thirdly, font style also requires additional processing. It is desirable to apply font style of the normal width without thin dash elements. In the most cases it concerns interface inscriptions and new created maps. On conventional maps font substitution and recompilation of inscriptions to apply them in electronic aids is a rather routine work resulting not only in facilitating of reading of cartographic images but cost increase of the final product.

In our opinion the problem of fonts in electronic edition needs to be detailed studied, investigated and recommendations concerning their use must be given.

There is a certain problem concerning lack of correspondence in rendering of geographical names outside of Ukraine in school atlases, school maps, aids and in other cartographical products (atlases and maps of the world) aimed at adult readers where geographical names outside of Ukraine are rendered according to the Instructions on rendering of geographical names outside of Ukraine from certain languages into Ukrainian, approved by the State Service of Geodesy, Cartography and Cadastre. In school atlases and maps geographical names outside of Ukraine are rendered according to the official Ukrainian Orthography, where a little attention is paid to geographical names outside of Ukraine and they are often too ukrainized. Differences in rendering of geographical names outside of Ukraine between Ukrainian Orthography and Instructions on rendering of geographical names outside of Ukraine from certain languages into Ukrainian concern mainly the rendering of Roman letters $\mathbf{G g}, \boldsymbol{H h}, \mathbf{I i}$ and yotized vowels (fig. 2).

It is necessary to build an architecture and contents of electronic aid taking into account current making changes. If aids are released on electronic carriers (CD, DVD etc.), changes can be made only by new edition. But if we organize and give an access for users to the necessary resource on-line it is possible to update information or make changes when it is necessary.

The editor in his/her work on creation of electronic aids for general educational institutions is faced a task to take into consideration age peculiarities of pupils. When with contents of a aid as a rule there are no problems, development of self-explanatory user interface is to a certain degree difficult, for it requires joint work of editor, programmer and designer.

The modern ECA has to contain material which goes beyond an education program for 6th-9th forms of a regular school, because 


\begin{tabular}{|c|c|c|}
\hline Original name & Name according to Instructions & $\begin{array}{c}\text { Name according to Ukrainian } \\
\text { Orthography }\end{array}$ \\
\hline Houston & Г'юстон & Хьюстон \\
\hline Mauritania & Маврітанія & Мавританія \\
\hline Madrid & Мадрід & Мадрид \\
\hline Sicilia & Сіцілія & Сицилія \\
\hline Coimbra & Коімбра & Коїмбра \\
\hline
\end{tabular}

Fig. 2. Differences in rendering of geographical names outside of Ukraine between Ukrainian Orthography and Instructions on rendering of geographical names outside of Ukraine from certain languages into Ukrainian

only such approach can facilitate the choice of schooling profile in the 10th-11th forms and sometimes influence on it.

When some domestic implementators make only the first steps in creation of computer-assisted educational tools for learning geography
- electronic aid „Economical and Social Geography of the World", the 10th-11th form (fig. 3). On the territory of Ukraine there are no such study manuals for school purposes and in the world there are those mainly as popular editions.
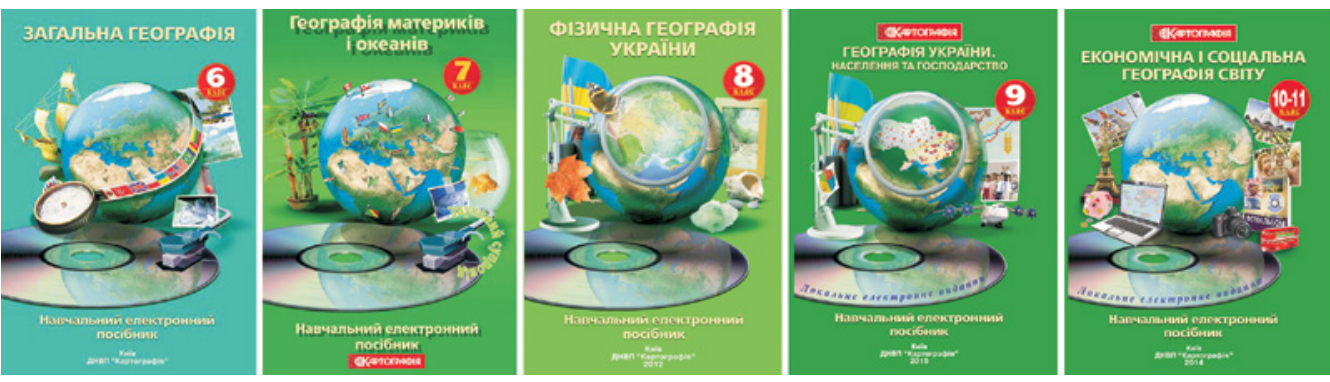

Fig. 3. Covers of electronic cartographic aids on geography developed in the DNVP "Kartographia"

in a school DNVP "Kartographia" (State Scientific and Production Enterprise "Kartographia") has achieved some success. A number of ECAs for general educational institutions have been developed and approved here:

- electronic aid "General Geography”, the 6th form;

- electronic aid "Geography of Continents and Oceans", the 7th form;

- electronic aid „Physical Geography of Ukraine", the 8th form;

- electronic aid "Geography of Ukraine. Population and Economy”, the 9th form;
All sections of each aid are integrated. Within each section theoretical material is presented, main conceptions are emphasized, there is a various number of diagrams, pictures, geographical maps facilitating learning of relevant topics. After each topic there are test exercises to form and check skills and knowledge of pupils on relevant topic. Advantages of use of slides and sources of any other information which help to concretize the learning material, reproduce feature forms or natural phenomena should be noted. Aids have an expanded splitlevel structure on the basis of modern techno- 
logical solutions and sound accompaniment.

ECAs contain an interesting geographical material which is functional, carries study load, has a methodical value, supply and expand pupil knowledge and is convenient to use. For maps of ECAs rich range of colors is characteristic. Knowledge system in the aid content is presented side by side with perception methods, in aid content there are content lines and didactic methods providing understanding by pupils of theoretical explanations by learning material. the user on the whole have been developed taking into account age category of pupils (fig. 4 and 5).

Implementation of aids mentioned above into teaching and learning activities of general educational institutions is slowed up by a number of factors. Firstly, technical equipment of schools requires better providing with video screen methods of information visualization (projectors, interactive whiteboards etc). Secondly, even technically equipped schools are not able to equip all classrooms with video screen

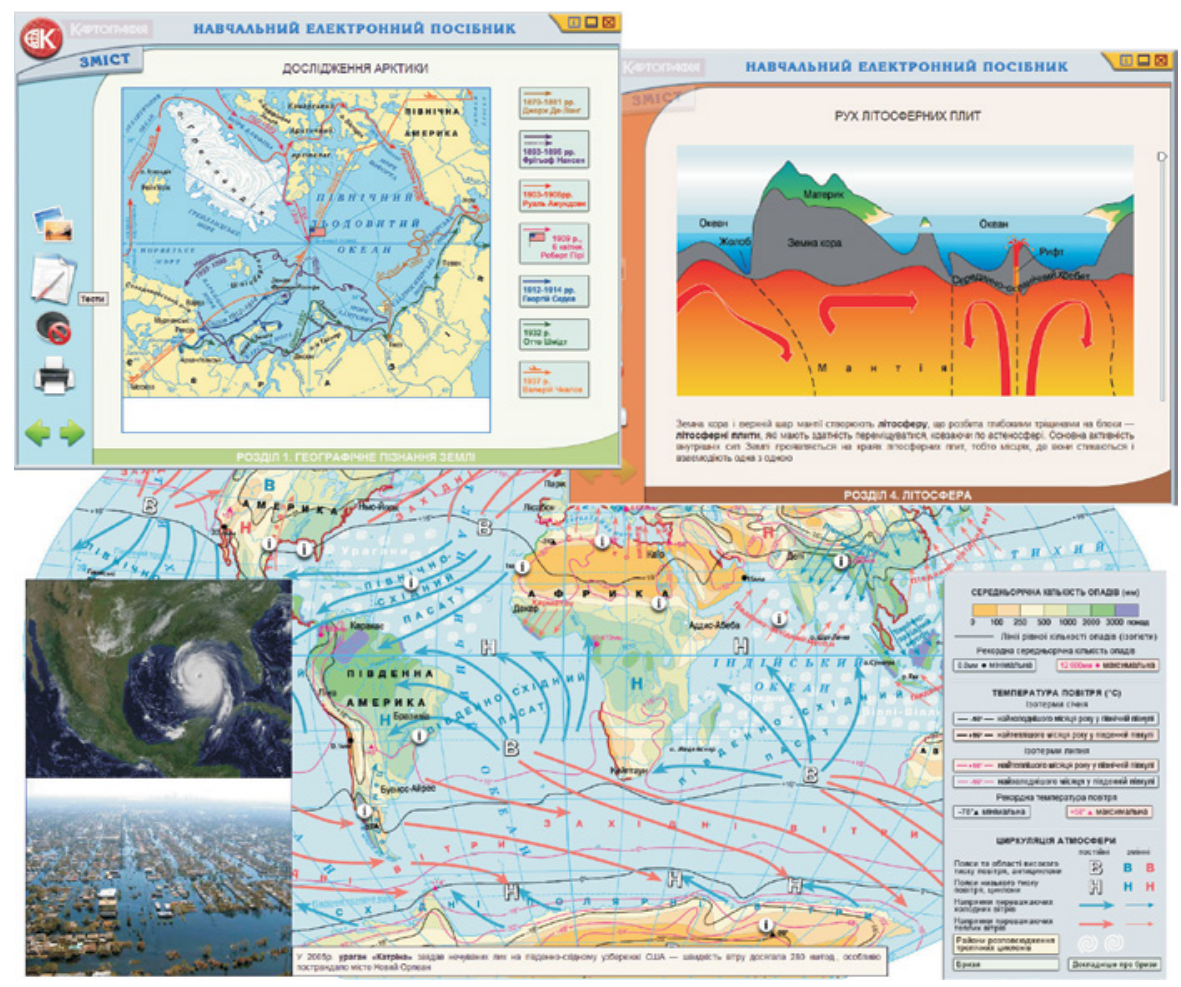

Fig. 4. Interface and contents of electronic cartographic aid "General Geography"

It should be noted, that electronic pages of aids are presented not as simple raster copies of the paper atlas, but they are filled with cross references, animated and dynamic images and all this is connected in rather comfortable and accessible interface of the user. All statistical, animated or combined images and interface of methods of information visualization. Thirdly, computer skills of geography teachers are very low, that's why information technologies in learning geography are integrated slowly. Efficiency of use of electronic cartographic materials on geography lessons remains a point for debate, this is because skill of working with maps 


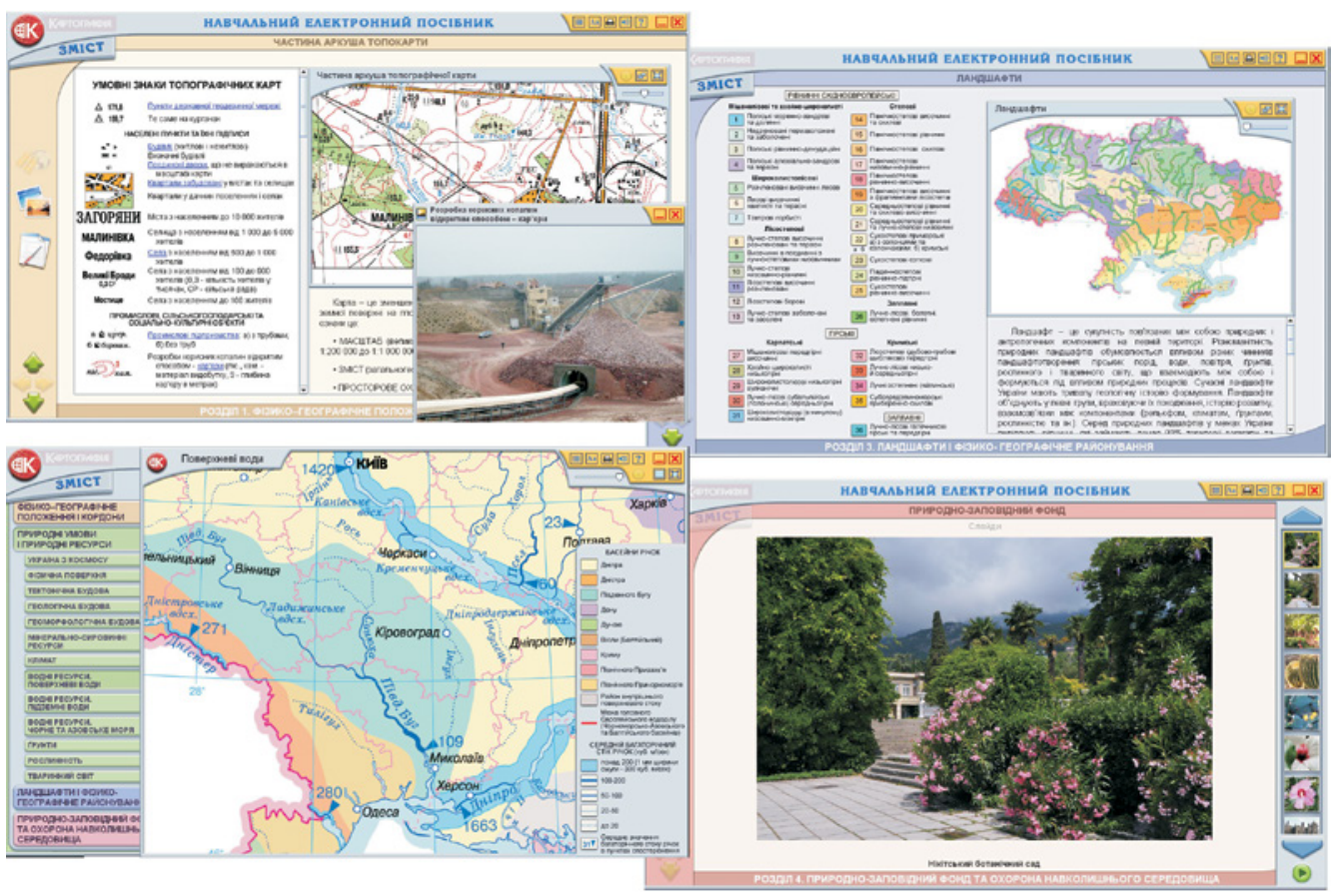

Fig. 5. Interface and contents of electronic cartographic aid "Physical Geography of Ukraine"

is a problem area for teachers. The way out is practical trainings for teachers with use of ECAs in the teaching and learning activities.

\section{Conclusions and prospects}

So using of system approach to creation of electronic cartographic aids allows to take a serious step forward changing from the cognitive model of education to the pragmatic one and facilitates a solution to the problem of creation of ECAs of new generation what enables to increase a number of users and using time, improve demonstrativeness of material presentation, to check obtained knowledge, facilitate optimal choice of schooling specialization in senior high school. ECAs facilitate to form in pupils holistic view of the environment, close relations of the nature, population and economy of the Earth, they develop in pupils spatial reasoning and what is the most important enable them to become modern, developed and computer-skilled people.
Thanks to use of system approach to creation of electronic cartographic aids new models of planning or giving a lesson may be used and modern instructional techniques may be implemented:

- education by means of interplay between listener and electronic educational resources by minimal participation of a teacher (self study). For development of these methods multimedia approach is characteristic;

- individualized teaching and learning, for which contacts between one pupil and one teacher or another pupil are characteristic (leaning "one to one"). It may be realized mainly by distance learning;

- presentation of educational material by teacher or educator to pupils when pupils do not play an active part in communication (learning "one to many"). These methods are proper for conventional educational system that undergoes a new development based on modern information technologies;

- Active cooperation among all participants of teaching and learning activities that is realized 
due to educational collective discussions and conferences.

That's why introduction of new information technologies into studies and pedagogical work will lead to fundamental changes of teacher's functions, a teacher together with pupils becomes more and more researcher, programmer, organizer and adviser.

General informatization of a society requires editors teams of cartographic enterprises and publishing houses to be sensitive to all events and changes in the development of modern presentation of geographical knowledge.

\section{References}

Drohushevska I.L., 2005, Rozrobka ta vprovadzhennia kompiuterno-oriientovanykh multymediinykh navchalnykh zasobiv $z$ heohrafii u zahalnoosvitnikh navchalnykh zakladakh (Development and implementation of computer-assisted multimedia educational tools on geography in general educational institutions). In: Natsionalne kartohrafuvannia: stan, problemy ta perspektyvy rozvytku, zb. nauk. prats. (National mapping: condition, problems and prospects of development: collected edition) Kyiv: DNVP «Kartohraphia” Vyp. 2, pp. 79-82.

Novytska L.V., 2007, Shkilna heohrafiia ta kompiuterni tekhnolohii: plidnyi tandem $v$ osviti (School geography and computer technologies: fruitful tandem in education). In: Problemy bezperervnoi heohrafichnoi osvity; zb. nauk. pr. (Problems of continual geographical education; collected edition), Kyiv: IPT, Vyp. 7, pp. 148-151.

Ostroukh V.I., 2011, Novitni elektronni navchalni posibnyky yak prodovzhennia protsesu peredachi systematyzovanykh znan, stvorennia novykh metodiv ta tekhnolohii navchannia (New electronic aids as extension of a process of systematic knowledge transfer, creation of new educational methods and technologies). In: V.I. Ostroukh, I.O. Yevropina (ed.), Problemy bezperervnoi heohrafichnoi osvity, zb. nauk. pr. (Problems of continual geographical education, collected edition), Kharkiv: KhNU im. V.N. Karazina, Vyp. 14, pp. 70-73.

Ostroukh V.I., 2013, Novi navchalni elektronni posibnyky z kursu "Fizychna heohrafiia v Ukraini" yak forma realizatsii innovatsiinykh tekhnolohii v osvitnomu protsesi (New educational electronic aids on the course "Physical Geography of Ukraine" as a realization of innovation technologies in the educational process), „Visn. heodez. ta kartohr” No. 1 , pp. $33-36$.

Sherman M.I., 2003, Elektronni zasoby podannia navchalnoho materialu yak component navchalnometodychnoho komplektu (Electronic tools of presentation of educational material as a component of learning package). In: Problemy suchasnoho pidruchnyka, zb. nauk. prats (Problems of the modern textbook, collected edition), Kyiv: Pedahohichna Dumka, Vyp. 4, pp. 42-46.

http://ukrmap.com.ua/catalog/navchalna-produktsija/elektronni-navchalni-posibniki/ 